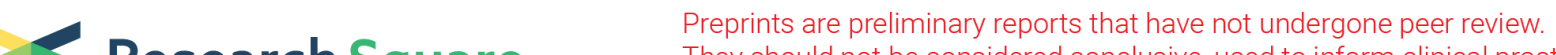 Research Square They should not be considered conclusive, used to inform clinical practice, or referenced by the media as validated information.
}

\section{Outdoor recreation planning and management considering FROS and Carrying capacities: A case study of forest wetland in Yeongam-gum, South Korea}

Hee Jeong Yun

Kangwon National University

Dong Jin Kang

Seoul National University

Youngeun Kang ( $\sim$ jiyoon8936@gmail.com )

Gyeongsang National University https://orcid.org/0000-0001-8376-7482

\section{Research Article}

Keywords: carrying capacity, forest wetland, FROS, LAC, landscape design, nature-based tourism

Posted Date: April 21st, 2021

DOl: https://doi.org/10.21203/rs.3.rs-429572/v1

License: (c) (1) This work is licensed under a Creative Commons Attribution 4.0 International License. Read Full License

Version of Record: A version of this preprint was published at Environment, Development and Sustainability on May 21st, 2021. See the published version at https://doi.org/10.1007/s10668-02101450-9. 


\section{Abstract}

Since demand for outdoor recreation in forests has been increasing, a structural planning framework for sustainable use while minimizing ecosystem degradation is needed. Utilizing the recreational opportunity spectrum (ROS) and carrying capacities (CC) have been long-standing tools in management outdoor recreation and tourism. Therefore, this study proposes using FROS (forest recreation outdoor system), LAC (limits of acceptable change), and CC for outdoor recreation in forest wetland in Youngam-gum, South Korea. An analysis of the spatial characteristics of the site-geological features, elevation, slope, viewshed, water system, forest age class, etc.--were carried out. Based on this analysis, an outdoor recreation planning and management framework was developed, including expert elicitation and a field survey of the site. This study found that (1) FROS classified the site as "rural developed" (zone 1), "rural natural" (zone 2), and "semi-primitive" (zone 3); (2) LAC considered spatial characteristics and tourism attractions network around the site by each zone; (3) and ecological CC (104.1-485.5 people per day), physical CC (130.9 445.1 people per day), and social CC (25 people for "PAOT," or "persons at one time") were proposed for sustainable management of the site. Compared to previous studies, this study has the novelty of suggesting an integrated outdoor recreation model for sustainable planning and management by introducing systematic zoning and coping with the changing environment. This result can be useful for policy-makers who are concerned with the outdoor recreation of forest wetland to conserve and utilize the site, and to prioritize suitable sites depending on the determining variables used in this study.

\section{Introduction}

Outdoor recreation demand for forests is continuously increasing due to recent changes in the social environment, such as increased leisure time, increased interest in forest health and healing functions, and increased leisure activities (Agimass et al. 2018; Elands and van Marwijk 2012; De Valck et al. 2017). Active participation in the outdoors not only provides enjoyment and adventure, but is also important for health and the promotion of conservation values (Brabyn and Sutton 2013). Recreation, especially in forests, takes the form of nature-based tourism or eco-tourism based on natural environments and nature experiences, and has proven its value by many researchers (Komossa et al. 2018) in terms of its health, ecological, and educational aspects. These recreation benefits constitute a substantial part of the total economic value of forests in modern societies, and are an increasingly important determinant in multifunctional forest management (Rolfe and Windle 2015).

To improve the quality of recreation, studies on the importance of space planning have been accumulating (Agimass et al. 2018; De Valck et al. 2017; Whiting et al. 2017). Although outdoor recreation depends significantly on the quality of the environmental settings (Aasetre et al. 2016), most of the approaches, which have explored the relationship between the setting and the recreational experiences, have ignored the spatial aspects of the experiences (Pietilä and Kangas 2015). Additionally, forest resources are the object of recreational use, as suggested above, and are also subject to conservation-but how to balance them is left a matter of controversy among researches (Eggers et al. 
2018; Heyman 2012). In order to consider this issue, many researchers have addressed the ecological impact from humans' recreational use of the forest, and have developed a suitability index to conserve and use forest resources, applying landscape characteristics (Morelle et al. 2018; Nino et al. 2017; Sardana et al. 2016). The ROS (Huang and Confer 2009; Gundersen et al. 2015) has also been utilized to determine the appropriate recreational site, as far as possible, to conserve forests. Since this ROS is originally from the concept of capacity to manage resources, objective standard or indicators to set the range of capacity towards resources is required. However, until now, the classification of types for providing recreational opportunities has remained at the conceptual level, and has been more focused on presenting recreational resource management plans rather than systematic approaches for analysis of suitable sites. That is, there is a lack of an objective approach in planning a recreational site in terms of conservation and its utilization within the site. In recent years, due to this shortcoming, the flow of studies has been changing from ROS-based recreational planning to developing 'Recreation Suitability' (Beeco et al., 2014; Caglayan et al., 2020). This approach enables us to select a suitable site from the viewpoint of conservation and use by applying various environmental and human use indicators and weights as well. Overall, the research question arises whether ROS based analysis, which is desirable for resource management, and the indicator-based analysis (GIS), which is desirable for location analysis can be combined in terms of sustainable forest conservation and use.

Therefore, this study aims to propose a systematic method for the conservation and sustainable use of forest wetlands by developing and applying indicator-based Recreational Opportunity Spectrum (ROS) and social carrying capacities (CC). It reflects both ecological aspects and recreational opportunities in Yeongam-gun, South Korea.

\section{Literature Review}

\subsection{Recreational Opportunity Spectrum (ROS)}

Among the various outdoor recreation management frameworks, the recreation opportunity spectrum (ROS) is one that is used to identify different outdoor recreation settings (Harshaw and Sheppard 2013). ROS is based on the hypothesis that recreational users' experience and motivation to visit a given site can be formalized in terms of a combination of environmental, managerial, and social factors (Clark and Stankey 1979). The key conceptual approach is that a recreational opportunity is when someone can undertake an activity, within a particular setting, and through it, gain an experience-hopefully a pleasant one (Joyce and Sutton 2009). One reason for its widespread use is that the ROS is useful for visualizing decision alternatives, and for communicating decisions to the public about how proposed actions could affect the site's recreation use and opportunity (Cerveny et al. 2011).

It is common to divide the rating of ROS into six categories: primitive, semi primitive-nonmotorized, semi primitive-motorized, roaded rural, rural areas, and urban areas. This distinction is derived from the ideas that differentiated management is necessary based on the characteristics of environments, taking into consideration long-term conservation and utilization. ROS ratings are normally determined based on 
remoteness and degree of naturalness in a conservation perspective. However, Driver, Brown et al. (1987) noted that rating the opportunity for recreation depends not only on the physical environment, but also on social and administrative environmental factors. In this context, related studies applied various methodological approaches, such as a population-based assessment for potential recreational use (Brabyn and Sutton 2013), a visitor experience-based assessment (Oishi 2013; Pietilä and Kangas 2015), and the relationship between visitor practices and site selection (Gonson et al. 2017). The main components determining the ROS ratings were the proportion of nature areas, its topography, accessibility, distance to a road, attractiveness within the region, and its unique features, as well as the presence of existing tourism infrastructure, etc. (Aasetre et al. 2016; Boyd and Butler, 1996; Nino et al. 2017 ) -in other words, its ecological and sociocultural factors. Considering the regional characteristics or differences in perspective, several studies (Gundersen et al. 2015; Joyce and Sutton 2009; Oishi 2013; Paracchini et al. 2014; Xiao et al. 2012) changed their ROS ratings into four-to-six categories. That is, ROS is a flexible and widespread framework that many studies could apply under various conditions. For example, Gundersen et al. (2015) divided ROS ratings into fours; general consideration, special consideration, service, and wilderness areas, from a management perspective.

Despite the ROS's benefits and application to many studies, its limitations have been pointed out (Harshaw and Sheppard 2013; Pierskalla et al. 2007), In particular, Harshaw and Sheppard (2013) insisted that a fundamental limitation of the ROS is that its framework is static and conceptual, which means that judgment is required in its interpretation and application. To fill this gap, researchers have suggested using a GIS-based spatial approach (Harshaw and Sheppard, 2013; Komossa et al. 2018; Nino et al. 2017; van der Zanden et al. 2018), or LAC, which enables a more accurate analysis so that decisionmakers can reflect it in their management plans. Harshaw and Sheppard (2013) found that ROS could be increased by merging it with other management frameworks, such as LAC. LAC was developed by the Forest Service in the 1980s and was developed further and proposed as an alternative model for making decisions about carrying capacity (Frissell and Stankey 1972; Stankey and McCool 1984). LAC involves identifying recreation opportunities and desired resources and social conditions for a particular area and evaluating the effects of change on those conditions (Cerveny et al. 2011). This indicates not only how much change can be prevented in the development, but also how much change can be allowed; it is therefore aimed at suggesting an appropriate management plan within a range that includes both recreational use and natural resource development.

In sum, ROS provides research opportunities for modelling recreation use (Brabyn and Sutton, 2013) with greater diversity and higher quality (Oishi 2013). Further, it is needed in order to meet the future challenges concerning development in public preferences, new users and activities, and both present and potential social conflict (Aasetre et al. 2016). Applying LAC and spatial analysis to ROS while considering potential use and conservation could be helpful for general land and resource management, even balancing supply and demand for visitors' potential use. Therefore, in this study, the recreational opportunity concept was applied to suggest the management of forest wetlands. It incorporates ideas from both the ROS and the Forest Recreation Opportunity Spectrum (FROS) from Xiao et al. (2012), who applied biophysical, social, and management attributes to their FROS framework. The ROS spectrum and 
LAC suggested here modified the concept of FROS to focus more on forest management from an outdoor recreational perspective, and intensified its delicate spatial analysis using GIS.

\subsection{Carrying Capacities}

Carrying capacity (CC) is an ecological concept that expresses the relationship between a population and the natural environment on which it depends for ongoing sustenance (Abernethy 2001). The concept of CC in tourism has its origin in the 1960s, when it was developed to place limits on the numbers of visitors that a tourist attraction or destination could cope with (Coccossis and Mexa 2004). Further, using this concept in a touristic area may generate a satisfactory experience for tourism with an "acceptable" or minimal impact on the resources of the protected area (Cupul-Magaña and Rodríguez-Troncoso 2017). Traditionally, it has been applied to beaches (Navarro et al. 2013; Rodella et al. 2017) to conserve the ocean environment and maintain the satisfaction of visitors by limiting the number of people that may visit a tourist destination. In recent year, this concept has been applied not only to beaches but also to other places such as forests and parks (Oh 2014; Zhang et al. 2017), where conservation needs to be balanced with recreational use.

$\mathrm{CC}$ in forest areas has been the basis of many visitor management strategies; it is closely related to the imbalance between supply and demand for forest recreation. For example, forests are visited intensively for short periods such as summer vacations, fall seasons, and festivals, but the number of visitors is relatively low for most periods. There are also significant differences between weekday and weekend visits. This demand imbalance means that the supply does not meet the demand momentarily as an economic concept, which implies that it affects the degradation of natural resources and the decrease in satisfaction of visiting due to congestion (Kim 2003). Therefore, the concept of CC should be introduced to minimize damage to ecological, historical, cultural, and physical environments, and to provide a level of utilization and management strategy that will give tourists high quality recreational experiences in forests.

Studies on CC principally aim to balance the conservation of the environment used for activities with management for sustainable growth (Corbau et al 2019), and Shelby and Heberlein (1986) suggested that it is common to divide this concept into three categories: a) ecological carrying capacity (ECC): finding limitations on how much changes such as natural destruction, damage, and loss can be accommodated; $b$ ) physical carrying capacity (PCC): determining the maximum number of people who can be accommodated in the entire space in terms of spatial maintenance; and c) social carrying capacity (SCC): finding the limit of the acceptable number of people to visitors a sense of psychological stability. These can be partially modified depending on the characteristics of the site to be applied and the feasibility of measurement.

In sum, the concept of CC implies conservation and management of the site ecologically, physically, and socially for environmental sustainability (Peng et al. 2018; Zeng et al. 2011; Zhang et al. 2017), and serves as an effective tool for environmental planning and decision-making (Cheng et al. 2019). 
Accordingly, in this study, the degree of ROS, LAC, and CC depending on the characteristics of the study site were calculated, and reflect the sustainable use of forest wetland.

\section{Methods}

\subsection{Conceptual framework}

Before approaching the ROS and social capacities of forest wetlands, it is necessary to discuss aspects of the "Ecosystem Service" concept provided by ecological assets. "Ecosystem service" refers to the comprehensive benefits of ecosystems to humanity's well-being, supporting survival and quality of life, and it is usually used as a tool for eco-environmental management (Ma, 2003; Zhang et al., 2020). Its value and importance have been increasing as rapid urbanization, biodiversity decline, ecologicalenvironmental deterioration, fine dust, and climate change threats increase (Saarikoski et al., 2015; Subiza-Perez et al., 2020). These types of services are largely divided into "Provisioning," "Regulating," and "Cultural recreation" functions (Osri et al., 2020). According to Osri et al. (2020), forest ecosystem services make a particular contribution to wood supply, water supply, erosion control, pollination habitat protection, soil formation, climate regulation, and recreation. They also generated the four bundles ("balanced," "wood and water," "soil carbon," and "rural recreational") of forest ecosystem services depending on the characteristics and tradeoffs provided by the ecosystem service. In addition, Grizzetti et al. (2019) quantified the ecosystem services and explored the relationship between these ecosystem services and the ecosystem condition to prepare for the current situation and establish a suitable utilization plan. Sun and Li (2017) also analyzed the tradeoffs and ecosystem services from land-use changes while pointing out the problem of reducing ecosystem services because of urbanization. As reviewed, there is an increasing effort to balance use and conservation by measuring the ecosystem services and analyzing tradeoffs as well.

The benefits of an ecosystem to humans are enormous and diverse; however, greater emphasis has been placed on resource utilization and development than on recognizing and managing the ecosystem as a limited resource. Therefore, it is necessary to continuously develop a practical tool that can evaluate the sustainability of land use by adopting the concept of ecosystem services, as discussed in previous studies. The EU has developed ROS in consideration of the aspect of use potential as well as ecosystem services. In this concept, the ROS approach was divided into two functions: "Accessibility" and "Recreational Potential." The accessibility analysis was divided into five stages (ranging from Very close to Very far from) using the matrix depending on "distance from roads" and "distances from urban areas." Recreational potential is usually analyzed using four indicators that are positively correlated with recreational activities. This analysis reflects conservation and utilization as well as minimizing the damage to the ecosystem in setting the level of recreational potential.

In this study, as described above, the perspective of ecosystem services was reflected in the development of indicators for FROS of forest wetlands. Moreover, with the premise of preserving the ecosystem, more emphasis was placed on the aspect of "efficiency" for humanity's recreational potential. Table 1 shows FROS functions and analysis indicators used in this study, reflecting the concept of ecosystem services. 
Table 1

FROS setting and analysis indicators considering the function of each type of ecosystem service.

\section{Types of The functions of forest wetlands Ecosystem \\ Services}

Provisioning - Supply of potential forest product resources from forests.

Regulating - Through material circulation performed by the forest ecosystem, ecosystem absorbs pollutants from the atmosphere, reduces temperature, absorbs carbon dioxide, and reduces damage from flood disasters.
FROS indicators used in this study

Water system, Catchment basin division, Forest age class division

Slope, Catchment basin division, Forest age class division, Ecological zoning map

Topographic map, Bird's eye view, Slope, Viewshed, Water system

\subsection{Study Site}

The study site is located in Ssanghyo-ri, Geumjeong-myeon, Yeongam-gun, Jeolla-do (South), South Korea, and its coordinates are latitude $34^{\circ} 50^{\prime} 39.2^{\prime \prime}-34^{\circ} 51^{\prime} 00.0^{\prime \prime}$ north, and longitude $126^{\circ} 48^{\prime} 07.4^{\prime \prime}-$ $126^{\circ} 48^{\prime} 44.2^{\prime \prime}$ east. This area was selected as a study site because its suitability for outdoor recreation in our previous study using an analytical hierarchical process (AHP) was the highest among 93 forest wetland sites in South Korea. The boundary of the site is shown in Fig. 1, and its total area is $69,434 \mathrm{~m}^{2}$. As shown in Fig. 2, the site was used as a rice paddy or farm in the past, and it was naturally abandoned and transformed into a forest wetland because of a decrease in rice production and agricultural population. (Korea Forest Service, 2014) Forest wetland formed by this process is a representative type that accounts for $73.4 \%$ of the total; in South Korea, others include the mountain valley type, mountain slope type, basin type, etc. (Korea Forest Service 2009; 2014). Specifically, the site has been formed as a ring-shaped linear shape along the route of the existing rice paddy, and the length of the site is $980 \mathrm{~m}$ running east and west, and $640 \mathrm{~m}$ wide. That is, it is a slender long area and with a half-moon shaped forest wetland.

\subsection{Measurement}

In this study, the measurement setting is divided into two parts: spatial characteristics measurements for FROS classification, and baseline measurements for determining carrying capacities.

Generally, ROS has been used for large landscapes (Harshaw and Sheppard, 2013) in order to describe a wide range of characteristics, i.e., primitive to suburban; it has been proposed, with limited classification, even in relatively small areas. Previous FROS (Xiao et al. 2012) have mainly assessed visitors' preference elements, such as facilities and service, wilderness, scenery, accessibility, transportation costs, perceived degree of crowding, etc. Oishi (2013) also suggested ROS in national parks to assess visitors' preferences 
regarding perceived trail condition, walking time to destination, naturalness, social encounters, visitor impacts (loss of vegetation), and so on. However, there is a limit to ROS's reliance only on visitors' demand, so we focused more on the supply aspect of forest wetland by analyzing its spatial characteristics. This specific analysis enables us to minimize ecosystem damage and make spatial planning fitted to the characteristics of site. Therefore, elevation, slope, geological features, viewshed (visibility), water system, catchment basin, ecological zoning map, vegetation, forest age class, land use, land ownership, and accessibility of the study site were analyzed based on previous related studies (Bunruamkaew and Murayama 2011; Ciesielski \& Stereńczak 2018; Gül et al. 2006; Korea Forest Service 2009; Korea Forest Service 2014; Feghhi et al. 2017; Vauhkonen and Ruotsalainen 2017).

Carrying capacity was calculated relying mainly on standards from existing studies. As suggested by Oh (2014), carrying capacities have been determined by vegetation damage, exotic species, water pollution, air pollution, soil erosion, etc., in ECC; facility size, accommodations, water and sewage, etc., in PCC; and the number of visitors, congestion, privacy violations, noise pollution, etc., in SCC. It is common for ECC to be calculated through on-site surveys toward natural resources of the site. Since ECC is determined by environmental impact according to the accumulation of total visitors, it should be set to a yearly unit. In the case of physical and social carrying capacities, they are normally influenced more by the concentration of visitors during the temporary period. Therefore, it is necessary to set these to a daily unit, in two categories: peak season, such as weekends and summer to fall, and off-season, such as weekdays and winter. Consequently, the ecological, physical, and social CC of this study were determined by the experts' elicitation based on comparing the calculated values of the existing studies.

\subsection{Spatial Characteristics and Division of Site by GIS}

The spatial analysis and division were designed to establish FROS zoning depending on the characteristics of the site. Spatial factors are increasingly receiving attention in environmental valuation (Abildtrup et al. 2013). Moreover, this could be useful in selecting and dividing suitable areas for outdoor recreation using the ROS concept at a site. As suggested in the Measurement Sect. (3.2) below, eleven factors were determined for spatial analysis using GIS: the elevation, slope, geological features, visibility, water system, catchment basin, ecological zoning map, forest age class, vegetation, land ownership, and accessibility (within and around the site). The GIS analysis was carried out using the ArcGIS plug-in for GIS 10.5, for elevation, slope, flow direction analysis, etc. The topographic map was analyzed at intervals of $5 \mathrm{~m}$, and a bird's eye view (http://map.vworld.kr) was utilized to determine the nearby mountains of the site. The grade of the slope analysis was divided into six degrees using the "natural break" function in ArcGIS. The geology of the site was obtained by the homepage (http://mgeo.kigam.re.kr/map), which provides the characteristics of geology of national scope. Observation points of the visibility analysis were set as the entrance point, nodal point, and the endpoint of the site, and the grades of the analysis were indicated by the number of times it was observed by visibility analysis. In other words, if all three points are visible in certain area within a site, it gets the value of 3; accordingly, visibility analysis could return values of $0,1,2$, or 3 . For the analysis of water system, the distance from the river were calculated using grade 1, 2, and 3 local stream data from the national stream geographic information system 
(https://www.river.go.kr/), and it was used as the evaluation index. In addition to this, we investigated stream, lake, and reservoir information, indicated in the digital topographic map $(1: 5,000)$ to determine the water system linked to the inside and outside of the site. Accordingly, the index of water system analysis was divided into four categories: agricultural irrigation canal, stream, river, and lake/reservoir, including site boundary. In catchment basin analysis, a flow direction analysis was performed using the DEM at a $10 \mathrm{~m}$ resolution, and the threshold formed in the water system was set based on the result of a flow accumulation analysis. With the ecological zoning map, the Ministry of Environment compiles and classifies ecological value, naturalness, and landscape values for mountains, rivers, wetlands, lakes, farmland, and cities throughout the whole country. It is classified into grade 1 (conservation), grade 2 (minimization of damage), and grade 3 (development), with separate management areas (legal protection areas) based on various natural environment information. The ecological zoning map analysis of this study site was analyzed using the data of the site boundary and the "join data from another layer based on spatial location" element of ArcGIS after obtaining a 1:25,000 ecological zoning map from environmental spatial information service site (http://egis.me.go.kr). The ecological zoning map of this study site was classified as grade 1 , grade 2 , and cultivated area, and grade 1 is recognized as the most conservative value. In the case of forest age class analysis, the data was constructed, digitized, and analyzed using the data of the site and the "join data from another spatial based on spatial location" element of ArcGIS using a map of the forest type (1:25,000) and a digitized forest map (1:5,000; http://11.67.44.22/forest/). This forest age class map enables us to grasp the forest conditions throughout the country, and it is divided into six grades depending on forest age. That is, the higher the score, the higher the age of the forest. In this study, the result of forest age class was classified into grade 2 age, grade 3 age, grade 4 age, and not applicable. The distribution of vegetation was analyzed by field surveys and reference data (Korea Arboretum Service, 2016). The land ownership was analyzed using a geographical map of Jeolla-do (South) from the national information portal (http://market.nsdi.go.kr). The standard of analysis was to determine whether the area is private property or not. Accessibility is quite a critical factor for attracting tourists when planning outdoor recreation of forest wetland. Therefore, in this study, we carried out a road network analysis around and within a site. The road information was analyzed through the road layer of 1:5,000 digital topographic map and national traffic analysis network data (http://www.ktdb.go.kr), and the distance from the study site was calculated using the "near" plug-in of ArcGIS.

After spatial characteristics were analyzed, the experts' elicitation was used to divide the zones (FROS) for desirable recreation and suggest the site management strategies (LAC) depending on divided zones considering spatial analysis results with carrying capacity determination. This process period was conducted from June to August 2018 through ten experts who are professors or researchers majoring in tourism development, landscape architecture, and regional planning.

\section{Results}




\subsection{Spatial Analysis Considering the Forest Wetland Attribute}

Figure 3 shows the spatial analysis results regarding geological features, elevation, slope, viewshed, water system, catchment basin division, the division based on the ecological zoning map, forest age class, land ownership division, land use division, and accessibility around and within the site.

As shown in (a) and (b) of Fig. 3, the north access road area of the site is $250 \mathrm{~m}$ above sea level, and the altitude of the southern end is $320 \mathrm{~m}$. There is a $70 \mathrm{~m}$ elevation difference between the lowest point and the highest point of the site. This difference in elevation is a geographical feature that influenced the formation of terraced rice paddies in the past. The steep slope in the northwest, $150 \mathrm{~m}$ above sea level, showed a tough basin terrain that is difficult to approach from the northwest. When planning the site, slope is a very important factor for the location of the building, facilities, and routes for circulation and traffic. The average slope of the site (see details in (c)) is not easy to develop at a $10.24 \%$ gradient, but the areas where the rice paddy was built was composed of flat land that can be developed feasibly. Specifically, the area between $5 \%$ and $12 \%$ was the largest with $42.5 \%$ of total, the steeply sloping area between $12 \%$ and $25 \%$ was $34.3 \%$, the area between $3 \%$ and $5 \%$ was $11.8 \%$, and the slope area of less than $3 \%$ was analyzed to be $10.5 \%$. In the analysis of visibility (d), the average visible size of $140,000 \mathrm{~m}^{2}$ was observed, which is a slightly surrounded area with limited visibility considering that the total area of site is $69,438 \mathrm{~m}^{2}$. As a result of water system analysis (e), it is necessary to consider the characteristics of the water level in the planning of the facilities because the water quantity near the site is low but the water inflow rate of the river is quite high and erosion may occur during the flood season. Also, it was found that most of the areas on the site appeared to be streams, and there were several streams near the entrance of the village around the site. In addition to water system analysis, basin catchment analysis is crucial to maintain the sustainability of forest wetland and ecological diversity in the future. It was found that the catchment area (f) through the inflow of surface water to the forest wetland was $530,507 \mathrm{~m}^{2}$ and formed the independent catchment unit, with the largest catchment area found at the entrance of the site. This means that surface water can be continuously introduced and the shape and function of the forest wetlands can be maintained with a habitat suitable for wild animals. For the division of the ecological zoning map $(\mathrm{g})$, the largest area was found to be cultivated $\left(34,099 \mathrm{~m}^{2}\right)$, which is not applicable in the ecological zoning map. The second grade area was $22,503 \mathrm{~m}^{2}$, and the first grade area was $12,832 \mathrm{~m}^{2}$, which is located innermost on site. Particularity, the areas distributed in first grade means that it has a rich ecological environment that needs to be conserved, and it can be a critical standard for determining FROS boundaries. The entrance area in the analysis of forest age class analysis ( $h$ ) appeared to be cultivated areas, and abandoned paddy fields and farms that were primarily grade 2 age, and higher altitude areas of the site were analyzed to be from grade 3 age to grade 4 age. The size of each area for forest age class, among the total area of $69,438 \mathrm{~m}^{2}$, is as follows: grade 2 age was the highest at 25,706 $\mathrm{m}^{2}$, grade 3 age was $19,856 \mathrm{~m}^{2}$, and grade 4 age was $17,048 \mathrm{~m}^{2}$. As a result of analyzing the current land use status (i), the total number of divisions for the site was 35 categories, and it was mainly composed of 
farmland, forest, road, farm, and artificial waterway. Specifically, most of the sites were composed of abandoned rice paddies, and the southwestern area of the site was composed of forests. Some of the areas included abandoned farms, and some areas have been transforming into wetlands since few areas were being used by humans. All areas of site appeared to be owned by the private sector (j), which is closely related to the feasible land purchase when planning in the future. Accessibility results ( $k$ and $\mathrm{I}$ ) showed there was no national road within a $1 \mathrm{~km}$ radius due to the spatial characteristics located in mountainous areas. The road within the site, including the mountain trail, were very complicated. This means that the roads within the site have been used for approaching the mountain and getting to the Buddhist temple called Ssanggyesaji, in addition to various agricultural purposes in the past. The main route in the site was linear, and the entrance to the village on the east side has some cement pavement, but most of the roads were unpaved. In particular, the boundary between the western part of forests was partially exposed due to steep slopes.

\subsection{Master Plan Based on FROS, LAC, and Carrying Capacities}

The FROS classification was determined through expert elicitation based on the analysis of spatial characteristics and a field survey of the study site. Relying on this, the site was divided into three areas: rural developed, rural natural, and semi-primitive, following Xiao et al. (2012), which recommended FROS in forest areas. This classification reflected not only the area's division depending on environmental and spatial characteristics, but also the process by which the abandoned rice paddies are transitioned into forest wetland at this site. Specific zoning areas on the site are shown in Fig. 4, and visitors' LAC was suggested depending on each zone's basic planning direction. As shown in Fig. 4, the areas closest to the village entrance on right side among the three divisions are the "rural developed" areas (zone I), while the middle area is "rural natural" (zone II), and the innermost area (zone III) contains the semi-primitive areas most in need of conservation.

First, FROS zone I is the entrance to the site, and is currently being used as a cultivated area or is left as abandoned rice paddies. The total area of this zone is $43,860 \mathrm{~m}^{2}$, which is the largest of the three zones, and is need of development with the highest development strength since it is the zone where the natural transition is the most recent. Therefore, the area should be able to accept recreational development and at the same time promote long-term sustainable development. A detailed planning strategy would include restoring the area to some extent by utilizing the characteristics of the existing areas, then building areas to create a concentration of facilities and programs in the form of experience tourism, through which visitors can experience the forest wetland areas, both in progress and completed. In addition to this, this zone should be equipped with facilities that can enhance the convenience of visitors and increase their period of stay, such as lodging facilities and food and beverage facilities using local food.

FROS zone II is located in the middle area of the study site, and most of area is currently laid out with abandoned rice paddies and farms. This area is also a buffer area between other two zones, and it is a suitable area to observe the process of transitioning from abandoned rice paddy to forest wetland. The 
total area of this is $15,347 \mathrm{~m}^{2}$, which is relatively small compared to zone I. The ecological environment of this zone is relatively good considering its ecological zoning map class (grade 2 ) and forest age class result (grade 3 age). Therefore, it is desirable to create a small observatory and education facility, appropriate to the size of the area.

FROS zone III is in the innermost areas of the site and is a semi-primitive area where the forest ecology system is mostly maintained. It should minimize the traffic of visitors reduce the possibility of damaging the ecological system or increasing its vulnerability. The total area of this zone is $10,231 \mathrm{~m}^{2}$, which is the smallest area. The ecological condition is very good considering that it is grade 1 on ecological zoning map and grade 4 age in forest age class. Therefore, it is necessary to establish this zone as an area that minimizes human use, allowing visitors to observe only the transitional process of forest wetland. However, this zone is located nearest to the historical and cultural districts, such as Ssanggye temple, Ssanggye bridge, etc. Accordingly, it can be competitive as a recreation site by linking this area to its historical and cultural districts. In this case, the connection between the two areas should minimize the damage to the ecosystem by using the existing farm roads and forest roads. The proposed images for the master plan and LAC by each zone can be found in Fig A1 and Table 2.

Table 2

Planning and management recommendations for each zoning of FROS

\begin{tabular}{|c|c|c|c|}
\hline FROS zoning & $\begin{array}{l}\text { Size } \\
\left(m^{2}\right)\end{array}$ & $\begin{array}{l}\text { Development } \\
\text { degree }\end{array}$ & Management recommendation (LAC) \\
\hline $\begin{array}{l}\text { Rural } \\
\text { developed } \\
\text { (zone I) }\end{array}$ & 43,860 & High & $\begin{array}{l}\text { - Restoration areas for terraced paddy fields } \\
\text { - Wise use areas } \\
\text { - Functional areas for experience, lodging, and } \\
\text { recreation in the form of experience tourism } \\
\text { - Experiential facility concentration area }\end{array}$ \\
\hline $\begin{array}{l}\text { Rural natural } \\
\text { (zone II) }\end{array}$ & 15,347 & Medium & $\begin{array}{l}\text { - Functions as buffer zone (management zone) } \\
\text { - Zone for observation, experience, and education of } \\
\text { forest wetland } \\
\text { - A medium density observation facility zone }\end{array}$ \\
\hline $\begin{array}{l}\text { Semi-primitive } \\
\text { (zone III) }\end{array}$ & 10,231 & Low & $\begin{array}{l}\text { - Forest wetland core conservation zone } \\
\text { - Minimum observing facility zone } \\
\text { - Regional tourism resource linkage zone (using } \\
\text { historical and cultural districts) }\end{array}$ \\
\hline
\end{tabular}

To develop the sustainable utilization model for forest wetland recreation, this study also analyzed the carrying capacities, which is the basis for plan direction and space size estimation. This is a resource- 
oriented approach in accordance with the resilience of resources.

Above all, the targets for each $\mathrm{CC}$ was carried out for the entire site, not for the zone, and the details are as follows. The ecological CC was estimated using the per capita area standard of "suburban natural park" of UNWTO (1983) and Inskeep (1991). This is because the target area is adjacent to the nearby farmhouse and includes some cultivated land similar to suburban natural areas suggested by previous studies. Specifically, the total area of target area was $69,438 \mathrm{~m}^{2}$, and the per capita standard of "suburban natural park" is 143-667 people per a day. Therefore, it was analyzed that between 104.1 and 495.5 people were desirable for the site by applying the standard formula above.

Visitors in the forest generally move in the form of "linear-type tourism," and the activities related with outdoor recreation in forest are carried out along earlier farm roads or forest roads. Accordingly, the estimation of the physical CC should be analyzed using linear route of the site. We analyzed the size of actual farm and forest roads within the site, and $4,451 \mathrm{~m}^{2}$ (the length of the earlier roads $x$ the width of the roads) was determined as the target area for estimating the physical CC at this site. Based on the criteria of the Korea Forest Service (2002) and the National Park Research Institute (2007), $10 \mathrm{~m}^{2} /$ people per a day as an optimum level and $34 \mathrm{~m}^{2} /$ people per a day as maximum level were set for estimating the final physical CC for this route. Therefore, the maximum number of visitors acceptable per day was 445.1 people, and the optimum use per day was 130.9 people for the physical $\mathrm{CC}$ at this site.

Finally, social CC was considered to be related to the capacity of activities and interpretation program. This is because social CC is connected to the perceptual awareness of the place, such as the perception of crowding, use density, and use satisfaction, unlike the above ecological and physical CC. In general, the number of visitors preferred at the same time when operating a specific program in forest area is 25 PAOT (persons at one time), and the maximum allowable number of visitors is 44 PAOT (Manning et al., 2002; National Park Research Institute, 2007). However, we determined that the maximum allowable number of visitors was not appropriate on this site, therefore, only 25 visitors per interpretation program are preferred for social CC. Details on the ecological, physical, and social CC presented above is provided in Table 3. 
Table 3

Ecological, physical, and social CC of the site

\begin{tabular}{|c|c|c|c|c|}
\hline Division & Target & $\begin{array}{l}\text { Size } \\
\left(m^{2}\right)\end{array}$ & $\begin{array}{l}\text { Carrying capacities } \\
\text { (person) }\end{array}$ & Recreation use density \\
\hline $\begin{array}{l}\text { Ecological } \\
\text { CC }\end{array}$ & $\begin{array}{l}\text { The whole of } \\
\text { the site }\end{array}$ & 69,438 & $\begin{array}{l}\text { 104.1-485.5/ per } \\
\text { day }\end{array}$ & \multirow{3}{*}{$\begin{array}{l}\text { - Peak season and weekends: } \\
450-490 / \text { per day } \\
\text { - Off-season and weekdays: } 100- \\
\text { 130/per day } \\
\text { - Program: } 25 \text { per each time }\end{array}$} \\
\hline $\begin{array}{l}\text { Physical } \\
\text { CC }\end{array}$ & Main traffic & 4,451 & $\begin{array}{l}\text { 130.9-445.1 / per } \\
\text { day }\end{array}$ & \\
\hline $\begin{array}{l}\text { Social } \\
\text { CC }\end{array}$ & $\begin{array}{l}\text { Interpretation } \\
\text { program }\end{array}$ & - & $25 /$ PAOT $^{*}$ & \\
\hline
\end{tabular}

\section{Discussion}

\subsection{The Applicability of the Planning Framework for Outdoor Recreation Developed in This Study}

The results of this study raise a number of issues regarding zoning, depending on FROS and LAC and the estimation of carrying capacities of recreational use for forest wetlands. Our results provide new insights on the question of how we use the forest resources wisely for recreational purposes without jeopardizing the sustainability of forest wetland. In particular, the demand for nature-based recreation has been on the rise as suggested in Vallecillo et al. (2019), and empirical research (Ulrich 1984) has shown that contact with nature reduces human stress. Further, outdoor recreation is an important means to engage with the natural environment and is often regarded as a public good or a cultural ecosystem service (Komossa et al. 2018). Therefore, the results from this study can help not only to develop the guidelines for outdoor recreation planning itself, but to respond to the changing environment toward public health by expanding the scope of recreational opportunities.

Numerous studies have reflected ROS to conserve natural environment and to promote recreational use. However, since previous studies set the ROS within a wide range of areas, there was a lack of the systematic analysis and planning strategy within a particular site. In this study, we analyzed the elevation, vegetation, accessibility, slope, surrounding conditions, etc., which can affect recreational use within the site, and suggested three types of zoning ("rural developed," "rural natural," and "semiprimitive") and management direction (LAC) with expert elicitation, as various spatial features can be distinguished from one another in a site like the one presented in this study. Additionally, it is essential to analyze the surroundings of the site in recreation planning, which should involve not only spatial characteristics but should also introduce tourist facilities and link to nearby tourist resources. 
This study analyzed the site, focusing on supply-based (i.e., resource-based) aspects when suggesting FROS, though previous studies have also emphasized the importance of demand-based aspects as well as ROS by investigating visitors' preferences in using outdoor recreation spaces. For example, the study by Oishi (2013) determined that most visitors preferred naturally conserved trails and accessible trails, and suggested that these findings should apply to outdoor recreational planning. Xiao et al. (2012) in particular examined the types of forest resources preferred by visitors on their ROS study, and found that the ROS used by the Forest Service and the preferred ROS division and potential activities by visitors are different. Our view throughout this review is that a pre-supply and post-demand preference analysis needs to be adopted. In other words, conducting a supply-based evaluation using the site characteristics of forest resources like the planning framework proposed in this study, and then investigating the preferences of visitors using each area is a way to improve visitors' satisfaction while conserving the ecosystem.

We also need to stress the limitations of this study. The planning framework for outdoor recreation lacks a concrete design guideline such as landscape composition, arrangement of facilities, or open spaces within a divided each zone. Existing studies (Agimass et al. 2018; Eggers et al. 2018) also pointed out that landscape elements and concrete planning are critical when it comes to improving visitors' recreation quality, satisfaction, and intention to revisit. Although we suggested an outdoor recreation planning and management framework focused mainly on a resource-based aspect analysis, we could find the clues for specific landscape guidelines based on the results from Peña et al. 2015, who suggested that open viewsheds are preferable to accessibility for recreational potential. Also, Hegetschweiler et al. (2017) suggested that having a mixture of old and young trees, or creating a mosaic of visually distinguishable stands for building structural diversity, is preferred. Besides, many researchers (De Valck et al. 2017; Sardana et al. 2016) have proposed a landscape guideline for outdoor recreation in the forest, which can be applied concurrently with the results of this study. Additionally, the site of this study has been transformed into a forest wetland from abandoned paddy fields; thus, there is a limit to the extent to which this result can be referred to as a conservation guideline for all forest wetlands. Therefore, it is considered desirable to compare and analyze similar forest wetland conservation guidelines and FROS results in the future.

Potential applications of this study include determining the standards for outdoor recreation suitability, applying the determinant factors not only in forest environment but also in other environments, and reflecting the forest planning and management decision-making process.

\subsection{Spatial Management Strategies and Polices Regarding Supply and Demand of Forest Wetland}

The management of natural resource-based areas such as forests is often more difficult than the management of facility-based areas due to the sensitivity of the natural resources and their need for conservation. The management and policy of forest use shows the importance of management by user preference for detailed demand policies (De Valck et al. 2017), and there has been an accumulation of 
studies that suggest the elaboration of the policy-making process using mapping analysis based on spatial characteristics (Peña et al. 2015). Especially in the mapping process for forest management, Schulze et al. (2019) criticized the fact that this mapping has been mainly performed by relying on forest land cover or deforestation patterns. Accordingly, they developed spatial patterns for forest management using predictor variables like tree density, forest loss, elevation, soil depth, drainage classes, aridity index, market accessibility, travel time to major cities, etc. This study, therefore, analyzed various site variables, and suggested ROS (FROS) based on the spatial analysis. The ROS was recognized as being superior in terms of the spatial classification that enables us to differentiate planning and management, but the lack of consideration of temporal elements remains one of the main criticisms of the ROS. In particular, recognizing the temporal dimension of forest management is a response to the dynamic nature of forests and changing societal demands for forest products and amenities (Harshaw and Sheppard 2013).

To fill this gap, this study introduced carrying capacities. It combined not only ecological CC, but also physical and social CC as perceived by visitors. This approach can be easily applied to policy-makers by presenting specific limitations (i.e., maximum occupancy of visitors) and establishing season-based differentiation (i.e., peak season, off-season, weekdays, and weekends). Since the results related to social capacity (social CC) are highly related perceived congestion, it is necessary to specify the appropriate capacity by referring existing papers which verified congestion decreases visitors' welfare (Douglas and Johnson, 1992; Gürlük, 2012; Gürlük et al., 2012; León et al., 2015). Based on the results of Gürlük et al. (2012), people are more willing to pay for urban forest with less congestion. Moreover, it was found that WTP amounts increase as those with higher sensitivity to sustainable development. In addition to this economic approach, a method of investigating visitor's perceived congestion or their willingness to revisit via structured survey would also be helpful for policy-makers to determine the extent of direct carrying capacity.

Since those are direct standards which can be compulsory, various strategies that support this result in an indirect way are necessary to implement this management policy. In this regard, the result from the National Park Research Institute (2007) is noteworthy. In their study, four types of practices were proposed for forest use recreation and management: 1) education, through an on-demand system for outdoor recreation, public advertisement, the activation of community programs by NGOs, providing information and incentives for low-density areas, a special protection areas notification, the introduction of a reservation system for visitors; 2) regional management, through a prevention-of-damage district, the improvement of tour routes to disperse visitors, and the restriction of facilities; 3 ) pricing, by introducing peak-load pricing and congestion pricing; and 4) activity limitation, through limiting swimming, camping, fishing, and rafting, depending on the season. Among these, the strategies of the restriction of facilities in order to reduce congestion can be extended or replaced in other ways. According to Gürlük et al. (2012), they proposed a policy to resource enlarging policy as well as visitation restriction policy to optimal carrying capacities for urban forests. However, this may not be suitable as a sustainable urban forest management because it is accompanied by additional land development or nature destruction. 
In this way, an analysis of forest resource characteristics from the supply perspective and the introduction of carrying capacities for recreational potential would be useful for policy-makers in forest resource management for recreational use. Direct and indirect strategies to encourage or restrict use should also be recommended for sustainable forest use.

\section{Conclusion}

When planning a tourist destination where conservation is needed along with recreational use, the perspective that the development range and activities that are acceptable must depend on the environment should be a fundamental goal of sustainable tourism, and empirical research on this subject is required. Therefore, in this study, FROS, LAC, and carrying capacities (ecological, physical, and social $\mathrm{CC}$ ) were investigated on the forest wetland in Youngam-gun, which was selected with high outdoor potential in our previous study. Since it was a site-based study, it presented not only a diverse evaluation at the landscape level, but also discussed the utilization of various outdoor recreational resources and the establishment of a conservation direction that should be considered by a field survey and an analysis of the surrounding area.

The main results of this study are as follows. First, FROS was developed by applying the concept of ROS toward forest wetlands, and it was divided into three zones ("rural developed," "rural natural," and "semiprimitive") according to the ecological and utilization characteristics of the forest wetlands. Second, based on the spatial characteristics and tourist attraction network of this site, the required LAC was proposed, and a management plan to minimize the use of areas with high conservation value was suggested. Finally, CC to accommodate the sustainable management of forest wetlands were 104.1 to 485.5 people per day for ecological CC, 130.9 to 445.1 people per day for physical CC, and 25 people at a time for social CC. The contribution of this study, which is differentiated from existing studies, is that it has developed ROS suitable for forest wetland, not for general urban forest. Moreover, it is highly feasible that can be applied directly by adopting substantial indicators such as land ownership, ecological zoning, road accessibility within and around the site.

Based on this study, it is recommended that effective recreational use opportunities be expanded within the management and reasonable range of forest resources, and further studies on various problems of using this framework through monitoring should be performed. The FROS, LAC, and carrying capacities frameworks in this study should also be applied to various other tourist destinations to ensure the conservation of resource and enhance the satisfaction of visitors. Our future research will focus on improving the quality of recreational use by conducting landscape preference as perceived by various types of users.

\section{Declarations}

\section{Acknowledgement}


This study was supported by Research Grant from Korea National Arboretum.

Conflict of Interest: There are no conflicts of interest to declare.

\section{References}

1. Aasetre J, Gundersen V, Vistad Ol, Holtrop EJ (2016) Recreational preferences along a naturalnessdevelopment continuum: Results from surveys in two unequal urban forests in Europe. Journal of Outdoor Recreation and Tourism, 16(March), 58-68. https://doi.org/10.1016/j.jort.2016.09.006

2. Abernethy VD (2001) Carrying capacity: The tradition and policy implications of limits. Ethics in Science and Environmental Politics (ESEP), 2001, 9-18.

3. Abildtrup J, Garcia S, Olsen SB, Stenger A (2013) Spatial preference heterogeneity in forest recreation. Ecological Economics, 92: 67-77. https://doi.org/10.1016/j.ecolecon.2013.01.001

4. Agimass F, Lundhede T, Panduro TE, Jacobsen JB (2018) The choice of forest site for recreation: A revealed preference analysis using spatial data. Ecosystem Services, 31: 445-454. https://doi.org/10.1016/j.ecoser.2017.11.016

5. Beeco JA, Hallo JC, Brownlee, MTJ (2014) GPS visitor tracking and recreation suitability mapping: Tools for understanding and managing visitor use. Landscape and Urban Planning, 127: 136-145. http://dx.doi.org/10.1016/j.landurbplan.2014.04.002

6. Boyd SW, Butler RW (1996) Managing ecotourism: An opportunity spectrum approach. Tourism Management 17(8): 557-566.

7. Brabyn L, Sutton S (2013) A population based assessment of the geographical accessibility of outdoor recreation opportunities in New Zealand. Applied Geography, 41: 124-131. https://doi.org/10.1016/j.apgeog.2013.03.013

8. Bunruamkaew K, Murayama Y (2011) Site suitability evaluation for ecotourism using GIS \& AHP: A case study of surat Thani Province, Thailand. Procedia - Social and Behavioral Sciences, 21: 269278. https://doi.org/10.1016/j.sbspro.2011.07.024

9. Caglayan I, Yesil A, Cieszewski C, Gul FK, Kabak O (2020) Mapping of recreation suitability in the Belgrad Forest Stands. Applied Geography, 116: 102153.

https://doi.org/10.1016/j.apgeog.2020.102153

10. Cerveny LK, Blahna DJ, Stern MJ, Mortimer MJ, Predmore SA, Freeman J (2011) The use of recreation planning tools in U.S. Forest Service NEPA assessments. Environ Manage 48:644-657

11. Cheng F, Su F, Chen M, Wang Q, Jiang H, Wang X (2019) An evolving assessment model for environmental carrying capacity: A case study of coral reef islands. Journal of Environmental Management, 233(July 2018), 543-552. https://doi.org/10.1016/J.JENVMAN.2018.12.047

12. Clark RM, Stankey GH (1979) The recreation opportunity spectrum: A framework for planning, management and research. General Technical Report PNW-98. Portland, Ore.: U.S. Department of Agriculture-Forest Service Northwest Forest Experiment Station. 
13. Corbau C, Benedetto G, Congiatu PP, Simeoni U, Carboni D (2019) Tourism analysis at Asinara Island (Italy): Carrying capacity and web evaluations in two pocket beaches. Ocean and Coastal Management, 169(September 2018), 27-36. https://doi.org/10.1016/j.ocecoaman.2018.12.004

14. Coccossis H, Mexa A (2004) The challenge of tourism carrying capacity assessment: Theory and practice. Aldershot: Ashgate.

15. Cupul-Magaña AL, Rodríguez-Troncoso AP (2017) Tourist carrying capacity at Islas Marietas National Park: An essential tool to protect the coral community. Applied Geography, 88: 15-23. https://doi.org/10.1016/j.apgeog.2017.08.021

16. De Valck J, Landuyt D, Broekx S, Liekens I, De Nocker L, Vranken L (2017) Outdoor recreation in various landscapes: Which site characteristics really matter? Land Use Policy, 65(July 2016), 186197. https://doi.org/10.1016/j.landusepol.2017.04.009

17. Douglas AJ, Johnson RL (1992) Congestion and recreation site demand: A model of demandinduced quality effects. Journal of Environmental Management, 36(3): 201-213.

18. Driver BL, Brown PJ, Stankey GH, Gregoire TG (1987) The ROS planning system: Evolution, basic concepts, and research needed. Leisure Sciences 9(3): 201-212 https://doi.org/10.1080/01490408709512160

19. Eggers J, Lindhagen A, Lind T, Lämås T, Öhman K (2018) Balancing landscape-level forest management between recreation and wood production. Urban Forestry and Urban Greening, 33(March), 1-11. https://doi.org/10.1016/j.ufug.2018.04.016

20. Elands BHM, van Marwijk RBM (2012) Policy and management for forest and nature based recreation and tourism. Forest Policy and Economics, 19: 1-3. https://doi.org/10.1016/j.forpol.2012.03.004

21. Feghhi J, Teimouri S, Makhdoum MF, Erfanifard Y, Abbaszadeh TN (2017) The assessment of degradation to sustainability in an urban forest ecosystem by GIS. Urban Forestry and Urban Greening, 27(October 2016), 383-389. https://doi.org/10.1016/j.ufug.2017.06.009

22. Frissell SS, Stankey GH (1972) Wilderness environmental quality: search for social and ecological harmony. In: Proceedings of the 1972 national convention; 1972 October 1-5; Hot Springs, AR. Washington, DC: Society of American Foresters: 170-183.

23. Gonson C, Pelletier D, Alban F, Giraud-Carrier C, Ferraris J (2017) Influence of settings management and protection status on recreational uses and pressures in marine protected areas. Journal of Environmental Management, 200: 170-185. https://doi.org/10.1016/j.jenvman.2017.05.051

24. Grizzetti B, Liquete C, Pistocchi A, Vigiak O, Zulian G, Bouraoui F, De Roo A, Cardoso AC (2019) Relationship between ecological condition and ecosystem services in European rivers, lakes and coastal waters. Science of the Total Environment, 671: 452-465. https://doi.org/10.1016/j.scitotenv.2019.03.155

25. Gül A, Örücü MK, Karaca Ö (2006) An approach for recreation suitability analysis to recreation planning in Gölcük nature park. Environmental Management, 37: 606-625. https://doi.org/10.1007/s00267-004-0322-4 
26. Gundersen V, Tangeland T, Kaltenborn BP (2015) Planning for recreation along the opportunity spectrum: The case of Oslo, Norway. Urban Forestry and Urban Greening, 14(2): 210-217. https://doi.org/10.1016/j.ufug.2015.01.006

27. Gürlük S (2012) Use of some components of new ecological paradigm scale on congestion pricing in a recreation area. Journal of Environmental Planning and Management, 56(10): 1468-1486. http://dx.doi.org/10.1080/10 14681486 09640568.2012.730480

28. Gürlük S, Atanur G, Turan Ö (2012) Economics of limiting congestion in urban forest recreation areas. Scandinavian Journal of Forest Research, 27(5): 449-459. http://dx.doi.org/10.1080/02827581.2012.657670

29. Harshaw HW, Sheppard SRJ (2013) Using the recreation opportunity spectrum to evaluate the temporal impacts of timber harvesting on outdoor recreation settings. Journal of Outdoor Recreation and Tourism, 1-2: 40-50. https://doi.org/10.1016/j.jort.2013.03.001

30. Hegetschweiler KT, Plum C, Fischer C, Brändli UB, Ginzler C, Hunziker M (2017) Towards a comprehensive social and natural scientific forest-recreation monitoring instrument: A prototypical approach. Landscape and Urban Planning, 167(June), 84-97. https://doi.org/10.1016/j.landurbplan.2017.06.002

31. Heyman E (2012) Analysing recreational values and management effects in an urban forest with the visitor-employed photography method. Urban Forestry and Urban Greening, 11(3): 267-277. https://doi.org/10.1016/j.ufug.2012.02.003

32. Huang C, Confer J (2009) Applying the tourism opportunity spectrum model in nature-based tourism management. Managing Leisure, 14(4): 247-257. https://doi.org/10.1080/13606710903204449

33. Inskeep, E (1991) Tourism Planning: An Integrated and Sustainable Development Approach. John Wiley \& Sons.

34. Joyce K, Sutton S (2009) A method for automatic generation of the Recreation Opportunity Spectrum in New Zealand. Applied Geography, 29(3): 409-418. https://doi.org/10.1016/j.apgeog.2008.11.006

35. Kim S (2003) Touristic Economics, Seoul: Baeksan publishing Co.

36. Komossa F, van der Zanden EH, Schulp CJE, Verburg PH (2018) Mapping landscape potential for outdoor recreation using different archetypical recreation user groups in the European Union. Ecological Indicators, 85(May 2017), 105-116. https://doi.org/10.1016/j.ecolind.2017.10.015

37. Korea Forest Service (2002) A study on the effective planning, operation, and management of arboretum and ecological forest. Korea Forest Service.

38. Korea Forest Service (2009) Report of wetland research of civil owned forest. Daejeon, Korea.

39. Korea Forest Service (2014) The investigation and monitoring for forest wetland. Daejeon, Korea.

40. León CJ, León J, Araña JE, González MM (2015) Tourists' preferences for congestion, residents' welfare and the ecosystems in a national park. Ecological Economics, 118: 21-29. http://dx.doi.org/10.1016/j.ecolecon.2015.07.003 
41. Ma (2003) Millennium Ecosystem Assessment: Ecosystems and Human Well-being. Is-land Press, Washington DC, USA.

42. Manning R, Wang B, Valliere W, Lawson S, Newman $P$ (2002) Research to estimate and manage carrying capacity of a tourist attraction: A study of Alcatraz Island, Journal of Sustainable Tourism, 10(5): 388-404.

43. Morelle K, Buchecker M, Kienast F, Tobias S (2018) Nearby outdoor recreation modelling: An agentbased approach. Urban Forestry and Urban Greening, (January), 0-1. https://doi.org/10.1016/j.ufug.2018.07.007

44. National Park Research Institute (2007) Carrying capacity management system of national park. National Park Research Institute.

45. Navarro JE, Damian IM, Fernández-Morales A (2013) Carrying capacity model applied in coastal destinations. Annals of Tourism Research, 43: 1-19. https://doi.org/10.1016/j.annals.2013.03.005

46. Nino K, Mamo Y, Mengesha G, Kibret KS (2017) GIS based ecotourism potential assessment in Munessa Shashemene Concession Forest and its surrounding area, Ethiopia. Applied Geography, 82: 48-58. https://doi.org/10.1016/j.apgeog.2017.02.010

47. Oh C (2014) Development of technique of environmental carrying capacity evaluation for sustainable eco-tourism industry, Seoul: Dongguk University.

48. Oishi Y (2013) Toward the improvement of trail classification in national parks using the recreation opportunity spectrum approach. Environmental Management, 51(6): 1126-1136. https://doi.org/10.1007/s00267-013-0040-x

49. Orsi F, Ciolli M, Primmer E, Varumo L, Geneletti D (2020) Mapping hotspots and bundles of forest ecosystem services across the European Union. Land Use Policy, 99: 104840. https://doi.org/10.1016/j.landusepol.2020.104840

50. Paracchini ML, Zulian G, Kopperoinen L, Maes J, Schägner JP et al. (2014) Mapping cultural ecosystem services: A framework to assess the potential for outdoor recreation across the EU. Ecological Indicators, 45: 371-385. https://doi.org/10.1016/j.ecolind.2014.04.018

51. Peña L, Casado-Arzuaga I, Onaindia M (2015) Mapping recreation supply and demand using an ecological and a socsial evaluation approach. Ecosystem Services, 13: 108-118. https://doi.org/10.1016/j.ecoser.2014.12.008

52. Peng B, Wang Y, Elahi E, Wei G (2018) Evaluation and Prediction of the Ecological Footprint and Ecological Carrying Capacity for Yangtze River Urban Agglomeration Based on the Grey Model. International Journal of Environmental Research and Public Health, 15(11): 2543. https://doi.org/10.3390/ijerph15112543

53. Pierskalla C, Lee M, Stein T, Anderson D, Nickerson R (2004) Understanding relationships among recreation opportunities: A meta-analysis of nine studies. Leisure Sciences, 26(2): 163-180.

54. Pietilä M, Kangas K (2015) Examining the relationship between recreation settings and experiences in Oulanka national park: A spatial approach. Journal of Outdoor Recreation and Tourism, 9: 26-36. https://doi.org/10.1016/j.jort.2015.03.004 
55. Rodella I, Corbau C, Simeoni U, Utizi K (2017) Assessment of the relationship between geomorphological evolution, carrying capacity and users' perception: Case studies in EmiliaRomagna (Italy). Tourism Management, 59: 7-22. https://doi.org/10.1016/j.tourman.2016.07.009

56. Rolfe J, Windle J (2015) Multifunctional recreation and nouveau heritage values in plantation forest. Journal of Forest Economics. 21: 131-151. https://doi.org/10.1016/j.jfe.2015.06.001

57. Saarikoski H, Jax K, Harrison PA, Primmer E, Barton DN, Mononen L, Vihervaara P, Furman E (2015) Exploring operational ecosystem service definitions: The case of boreal forest. Ecosystem Service. 14: 144-157.

58. Sardana K, Bergstrom JC, Bowker JM (2016) Valuing setting-based recreation for selected visitors to national forests in the southern United States. Journal of Environmental Management, 183: 972979. https://doi.org/10.1016/j.jenvman.2016.09.050

59. Schulze K, Malek Ž, Verburg PH (2019) Towards better mapping of forest management patterns: A global allocation approach. Forest Ecology and Management, 432(March 2018), 776-785. https://doi.org/10.1016/j.foreco.2018.10.001

60. Shelby B, Heberlein TA (1986) Carrying Capacity in Recreation Setting, Oregon State University Press.

61. Stankey GH, McCool SF (1984) Carrying capacity in recreational settings: evolution, appraisal, and application. Leisure Sciences. 6: 453-473.

62. Subiza-Perez M, Vozmediano L, Juan CS (2020) Green and blue settings as providers of mental health ecosystem services: Comparing urban beaches and parks and building a predictive model of psychological restoration. Landscape and Urban Planning. 204: 103926. https://doi.org/10.1016/j.landurbplan.2020.103926.

63. Sun X, Li F (2017) Spatiotemporal assessment and trade-offs of multiple ecosystem services based on land use changes in Zengcheng, China. Science of the Total Environment, 609: 1569-1581. http://dx.doi.org/10.1016/j.scitotenv.2017.07.221

64. Ulrich RS (1984) View through a window may influence recovery from surgery. Science 224: 420-421. 65. UNWTO (1983) Risks of Saturation or Tourist Carrying Capacity Overload in Holiday Destinations. Madrid: United Nations World Tourism Organization

66. Vallecillo S, La Notte A, Zulian G, Ferrini S, Maes J (2019) Ecosystem services accounts: Valuing the actual flow of nature-based recreation from ecosystems to people. Ecological Modelling, 392(September 2018), 196-211. https://doi.org/10.1016/j.ecolmodel.2018.09.023

67. Vauhkonen J, Ruotsalainen R (2017) Assessing the provisioning potential of ecosystem services in a Scandinavian boreal forest: Suitability and tradeoff analyses on grid-based wall-to-wall forest inventory data. Forest Ecology and Management, 389: 272-284. https://doi.org/10.1016/j.foreco.2016.12.005

68. Whiting JW, Larson LR, Green GT, Kralowec C (2017) Outdoor recreation motivation and site preferences across diverse racial/ethnic groups: A case study of Georgia state parks. Journal of Outdoor Recreation and Tourism, 18(February), 10-21. https://doi.org/10.1016/j.jort.2017.02.001 
69. Xiao S, Jia L, Jiang L (2012) Forest Recreation Opportunity Spectrum in the Suburban Mountainous Region of Beijing. Journal of Urban Planning and Development, 138(4): 335-341. https://doi.org/10.1061/(ASCE)UP.1943-5444.0000125

70. Zeng, C., Liu, Y., Liu, Y., Hu, J., Bai, X., \& Yang, X. (2011). An integrated approach for assessing aquatic ecological carrying capacity: A case study of Wujin District in the Tai Lake Basin, China. International Journal of Environmental Research and Public Health, 8(1), 264-280.

https://doi.org/10.3390/ijerph8010264

71. Zhang H, Pang Q, Hua Y, Li X, Liu K (2020) Linking ecological red lines and public perceptions of ecosystem servicess to manage the ecological environment: A case study in the Fenghe River watershed of Xi'an, Ecological Indicators, 113: 106218.

http://doi.org/10.1016/j.ecolind.2020.106218

72. Zhang Y, Li X, Su Q (2017) Does spatial layout matter to theme park tourism carrying capacity? Tourism Management, 61: 82-95. https://doi.org/10.1016/j.tourman.2017.01.020

\section{Figures}
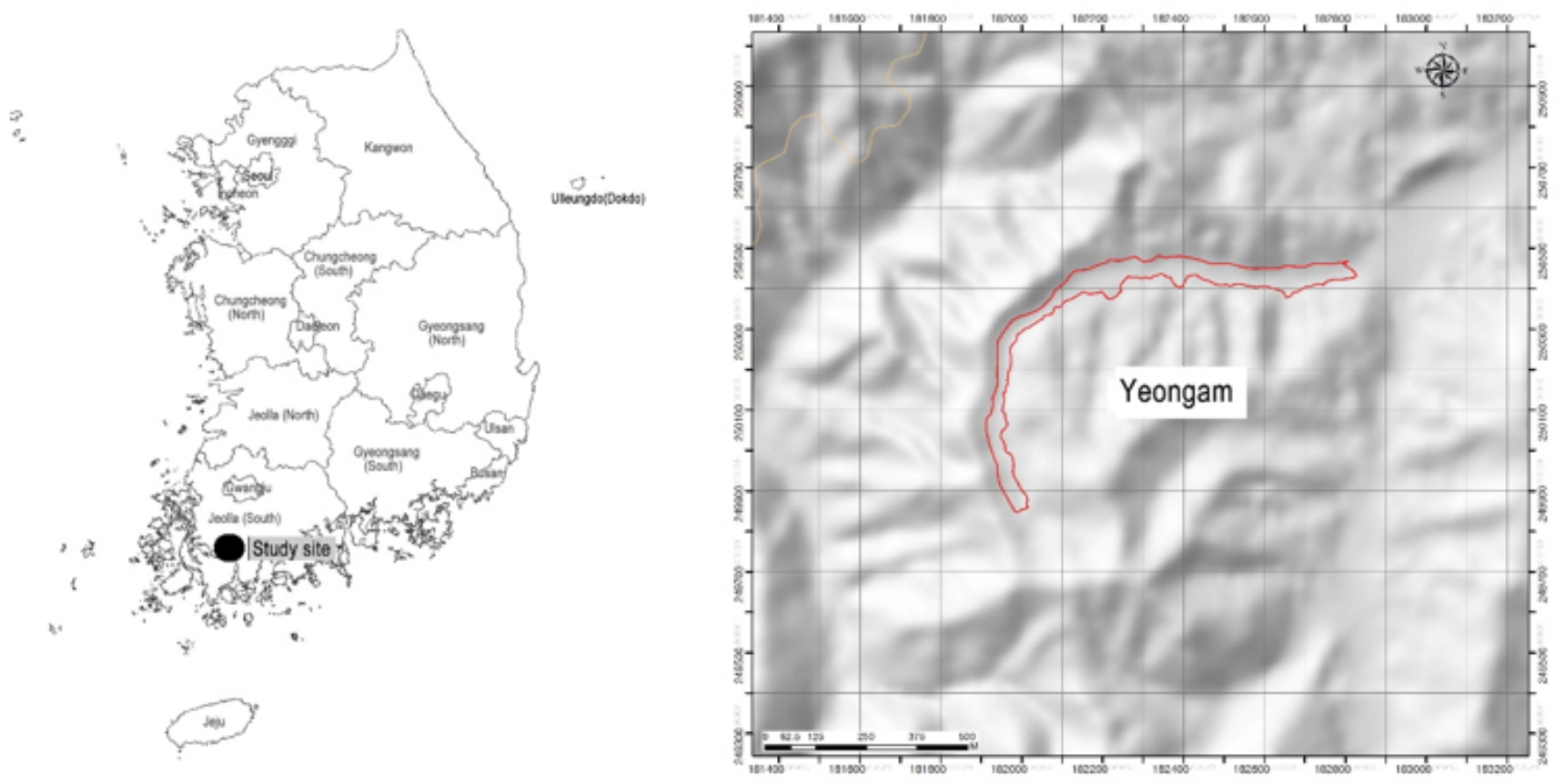

\section{Figure 1}

The location of study site (scale of right map: 1:25,000; resolution: $100 \mathrm{~m} * 100 \mathrm{~m}$ ). Note: The designations employed and the presentation of the material on this map do not imply the expression of any opinion whatsoever on the part of Research Square concerning the legal status of any country, territory, city or area or of its authorities, or concerning the delimitation of its frontiers or boundaries. This map has been provided by the authors. 


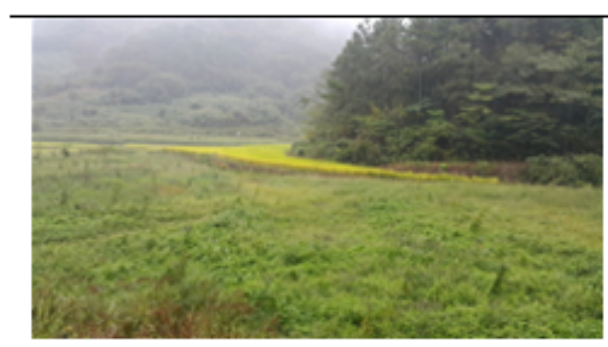

(a)

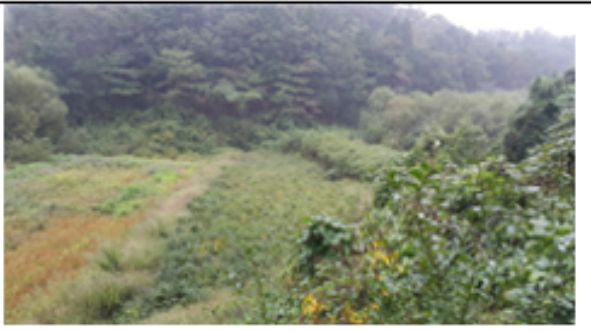

(b)

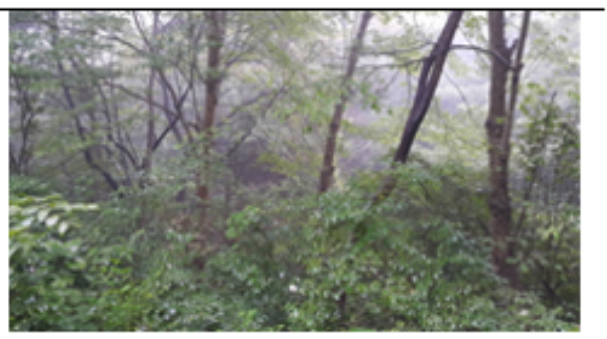

(c)

\section{Figure 2}

Current statues of the study site taken by authors: (a) abandoned rice paddy, (b) abandoned farm, (c) forest wetland on the western boundary of the site. 

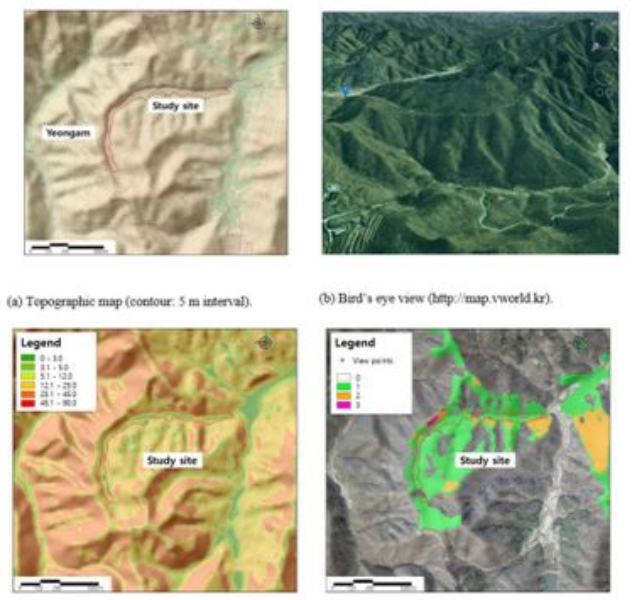

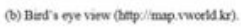
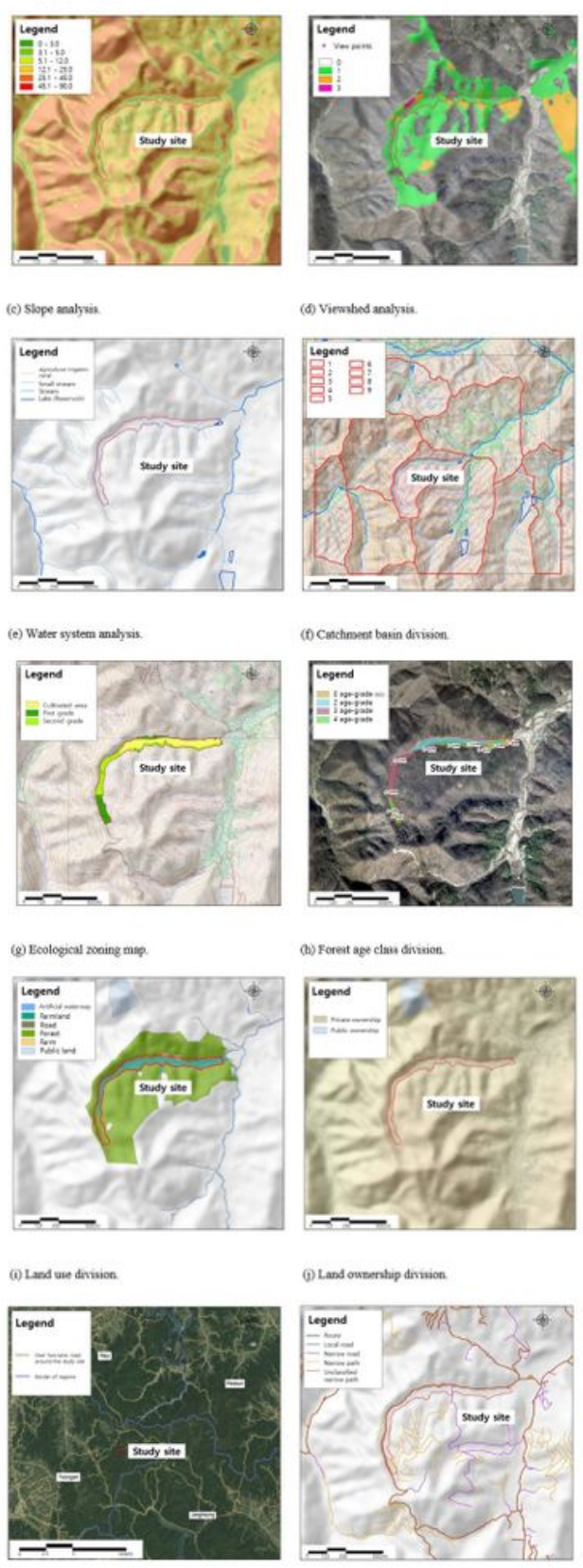

(0) Row accesublity arous the itite

(a) Road aceessiblity wethin the stite

Figure 3

Spatial analysis results of the site. Note: The designations employed and the presentation of the material on this map do not imply the expression of any opinion whatsoever on the part of Research Square concerning the legal status of any country, territory, city or area or of its authorities, or concerning the delimitation of its frontiers or boundaries. This map has been provided by the authors. 


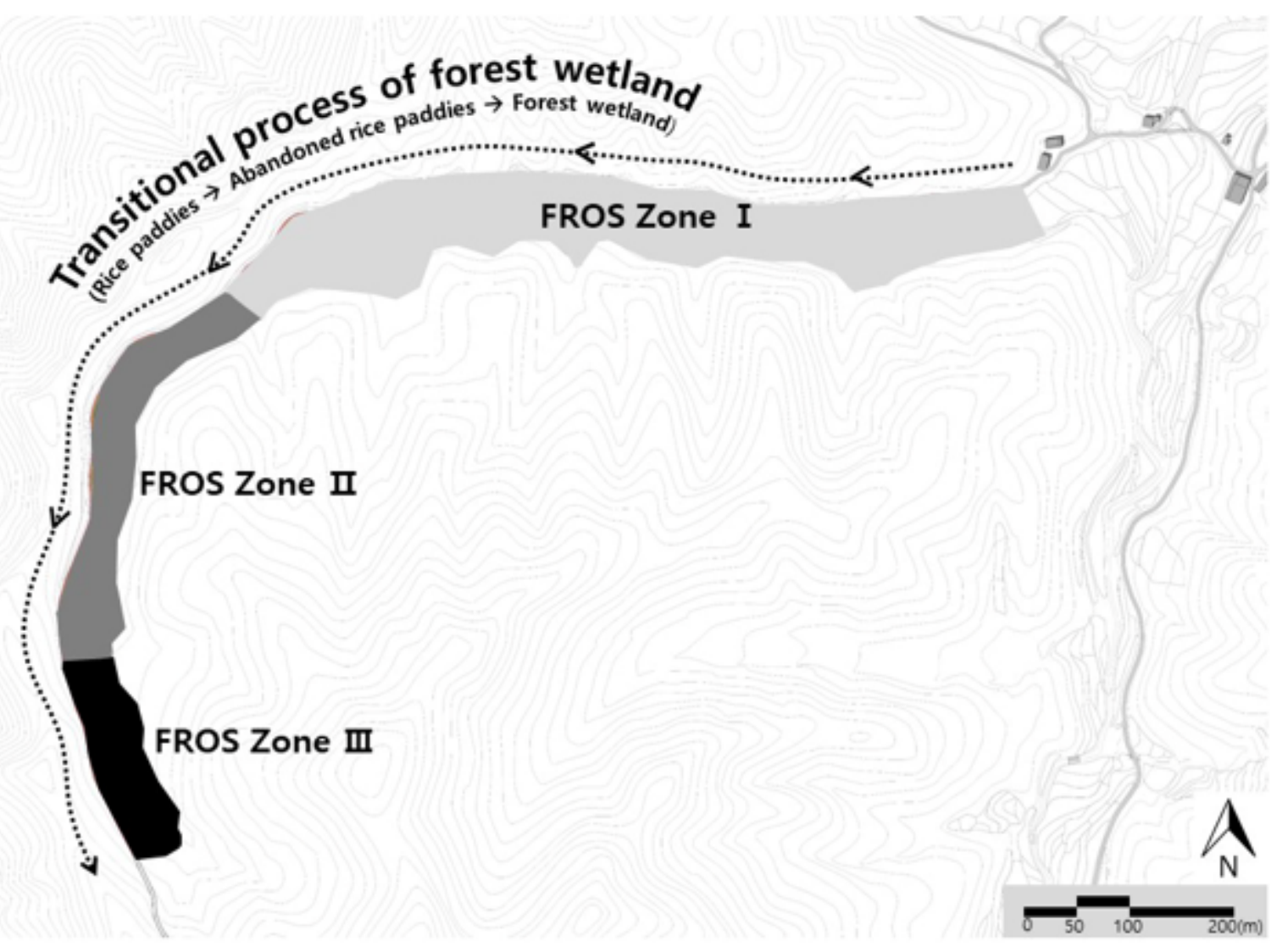

Figure 4

FROS division of the site. (Drawn by the authors). Note: The designations employed and the presentation of the material on this map do not imply the expression of any opinion whatsoever on the part of Research Square concerning the legal status of any country, territory, city or area or of its authorities, or concerning the delimitation of its frontiers or boundaries. This map has been provided by the authors.

\section{Supplementary Files}

This is a list of supplementary files associated with this preprint. Click to download.

- Appendix.docx 